\title{
Analysis of Longitudinal Cracks in Multilayered Beams with Account of the Material Nonlinearity
}

\author{
V. I. Rizov \\ Department of Technical Mechanics, University of Architecture, Civil Engineering and Geodesy, \\ Sofia, Bulgaria \\ V_RIZOV_FHE@uagg.bg \\ УДК 539.4

\section{Аналитический расчет прочности многослойных балок с продольной трещиной с учетом неупругости материала}

\section{В. И. Ризов}

Факультет технической механики, Университет архитектуры, гражданского строительства и геодезии, София, Болгария

В рамках классической теории балок на основании критерия скорости высвобождения энергии деформации выполнен аналитический расчет прочности многослойных балок с продольной трещиной с учетом неупругости материала. Полученные расчетные соотношения применимы к многослойным балкам со слоями различной толщины, напряженно-деформированное состояние каждого из которых может описываться индивидуальным нелинейным уравнением напряжение-деформация. Для продольной трещчнь с произвольньм расположением по высоте балки определяется скорость высвобождения энергии деформации как функиия изгибающих моментов и осевых нагрузок, действующих в сечениях балки, расположенных впереди и позади фронта трещины. Таким образом можно определить условия разрушения многослойных балок в замкнутом виде. Предложенный подход позволяет выявить особенности неупругого деформирования и разрушения многослойных балок с трещиной.

Ключевые слова: многослойные балки, продольное разрушение, неупругий материал, скорость высвобождения энергии деформации.

Introduction. Multilayered materials are frequently used in structural applications where barrier properties, strength and weight are an issue. Longitudinal (interface) fracture is the primary concern with multilayered structures. The engineering practice shows that this type of fracture is very often the earliest failure mode. Longitudinal fracture may initiate from various defects induced during manufacturing process or from damages inflicted during lifetime of the multilayered structure. Therefore, the longitudinal fracture should be considered in the evaluation of multilayered structures for functionality and reliability. Over the years, various studies have been reported on the longitudinal fracture issue [1-6]. The majority of these studies has been concerned with longitudinal fracture in beam configurations such as the double cantilever beam (DCB), the end notched flexure (ENF), the end loaded split (ELS), and others.

Longitudinal fracture behavior of multilayered beams subjected to four-point bending has been analyzed by Hsueh et al. [7]. For this purpose, the classical beam theory has been applied. Fracture has been studied in terms of the strain energy release rate. A closed form analytical solution has been obtained by using the methods of linear-elastic fracture mechanics. The solution is applicable to linear-elastic multilayered beam systems with any number of layers. Also, the longitudinal fracture can occur at any interface. 
The interfacial fracture toughness of a four-layer linear-elastic beam structure has been analyzed in [8]. It has been assumed that a longitudinal crack is located between the second and the third layers. A formula for the strain energy release rate has been derived by using the classical beam theory. The fracture has been studied in a function of modulus of elasticity and thickness of the layers.

It can be generalized that linear-elastic fracture mechanics approach has usually been used to analyze longitudinal fracture in multilayered beams. This approach is based on the assumption for validity of Hooke's law. However, in reality multilayered structures can exhibit material nonlinearity. Therefore, the basic purpose of the present article is to perform a theoretical study of longitudinal fracture behavior of multilayered beam configurations with taking into account the material nonlinearity. The study was carried out in terms of the strain energy release rate by using the classical beam theory.

1. Fracture Analysis with Considering the Material Nonlinearity. A multilayered beam with a longitudinal crack located arbitrary along the beam cross-section height (the lower and the upper crack arm thickness is $h_{1}$ and $h_{2}$, respectively) is under consideration in the present article. A perfect adhesion is assumed between layers. The beam height is $2 h$.

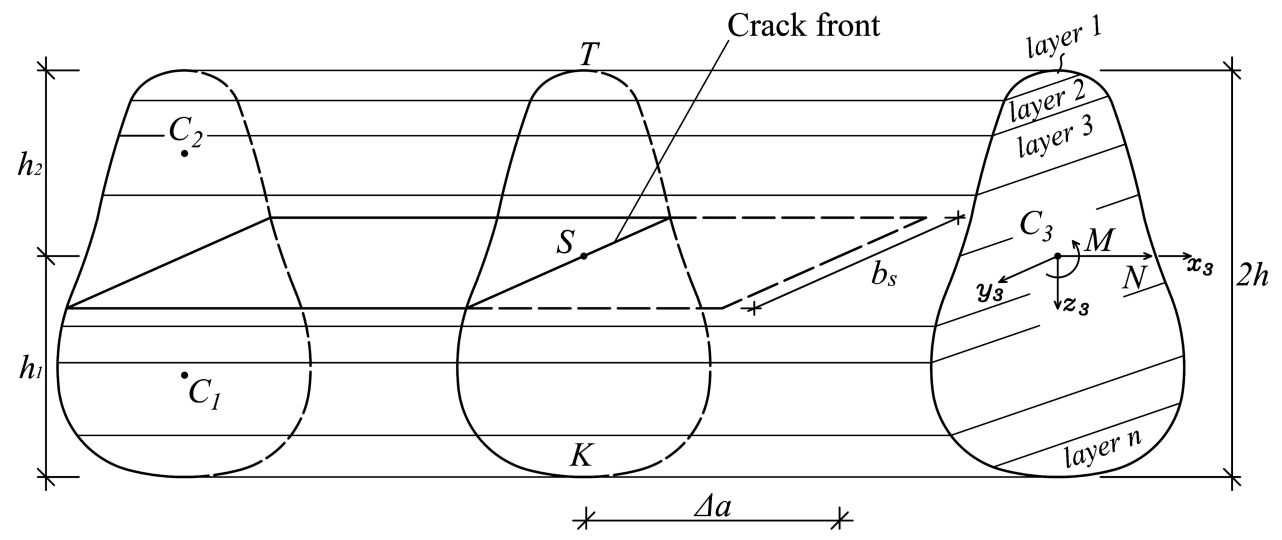

Fig. 1. Portion of a multilayered beam with the crack front.

The beam cross section is symmetric with respect to the $z_{3}$-axis. A beam portion with the crack front is shown in Fig. 1. The bending moment and axial force in the cross section ahead of the crack front are $M$ and $N$, respectively (the shear force is neglected, because long beams are considered). If the crack length increases with $\Delta a$, the normal stresses and linear strains distribution in the beam cross section, $T K$, (Fig. 1) will change from the one shown in Fig. 2 to that illustrated in Fig. 3. It was assumed that the mechanical behavior of the beam layers can be described by nonlinear stress-strain curves (Fig. 4). The stressstrain relations in the beam layers can be written as

$$
\sigma_{i}=\sigma_{i}\left(\varepsilon_{i}\right), \quad i=1,2, \ldots, n,
$$

where $\sigma_{i}$ is the normal stresses distribution, $\varepsilon_{i}$ is the linear strains distribution in the $i$ th beam layer, and $n$ is the number of layers. The material constants in Eq. (1) may differ for each layer. Moreover, the stress-strain relations may also be differ for each layer. Thus, the normal stresses distributions along the height of the multilayered beam cross section are different in each layer as illustrated in Figs. 2 and 3.

The aim of the present paper was to develop a general analysis of the crack problem shown in Fig. 1 with the account of the material nonlinearity. The analysis was carried out in terms of the strain energy release rate by using the classical beam theory. In principle, the 


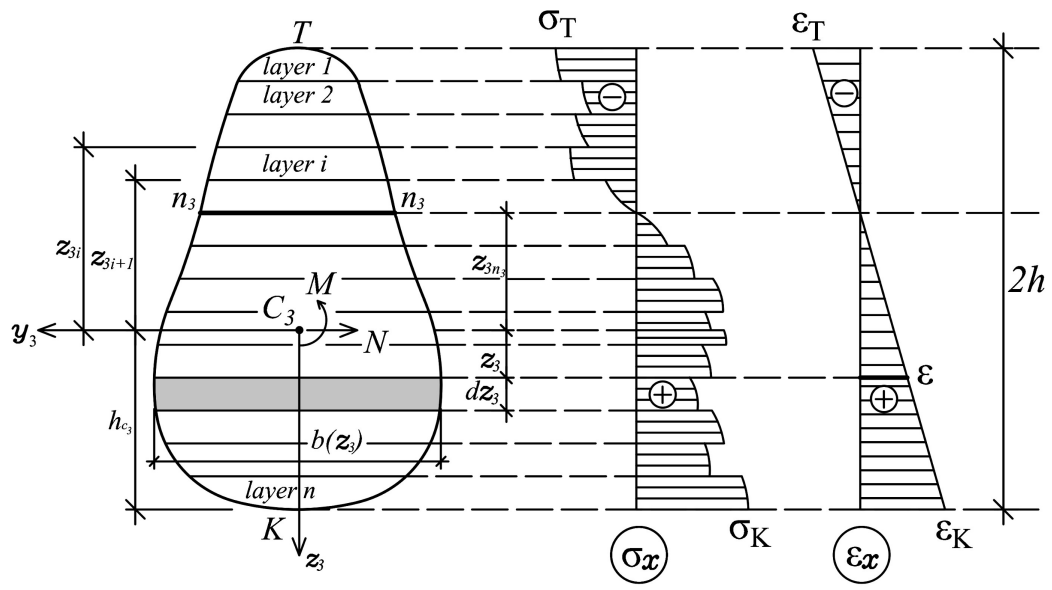

Fig. 2. Distribution of normal stresses and strains in the multilayered beam cross section $T K$ (refer to Fig. 1) before increase of the crack length.

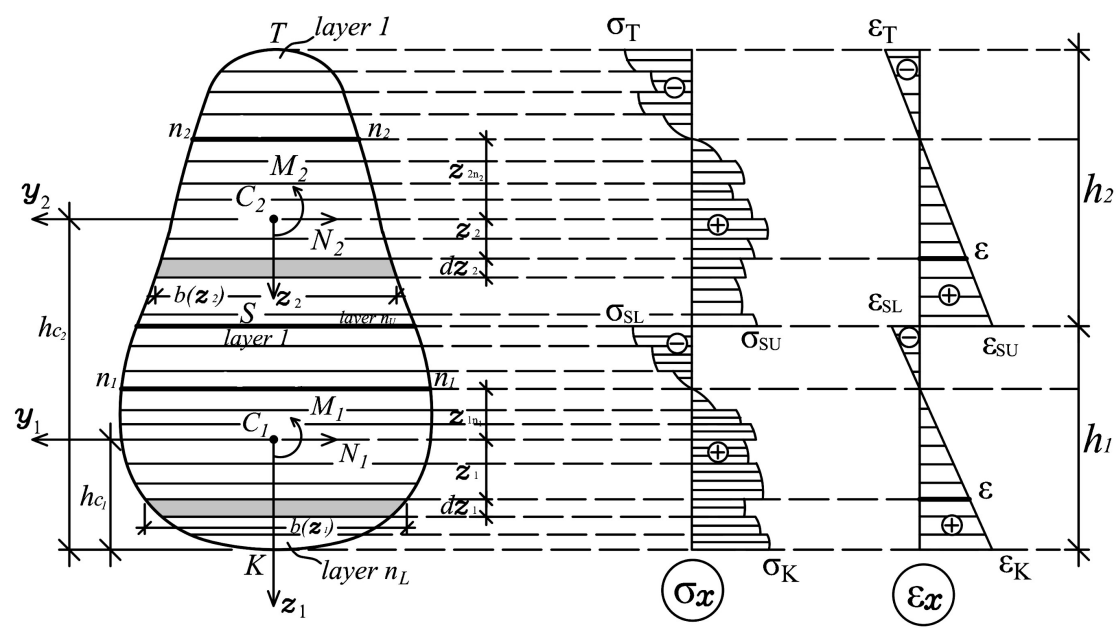

Fig. 3. Distribution of normal stresses and strains in the crack arms cross sections after increase of the crack length.

analysis developed in the present paper can be applied to nonlinear elastic multilayered beams (the analysis is applicable also for elastic-plastic behavior, if the external load magnitude increases only, i.e., if the beam undergoes active deformation [9-12]). The strain energy release rate is defined as

$$
G=-\frac{\Delta U}{\Delta A_{a}}
$$

where

$$
\Delta U=U_{b}-U_{a}
$$

is the strain energy variation (while $U_{b}$ and $U_{a}$ are the strain energies before and after the increase of the crack, respectively) when the crack area increases by the increment

$$
\Delta A_{a}=b_{s} \Delta a .
$$




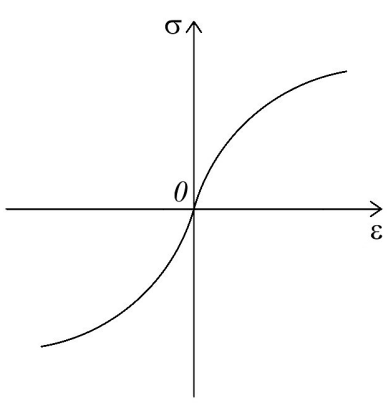

Fig. 4. Nonlinear stress-strain curve.

Here $b_{s}$ is the beam cross-sectional width at the crack level (Fig. 1). Thus, Eq. (2) can be rewritten as

$$
G=\frac{U_{a}-U_{b}}{b_{s} \Delta a}
$$

The strain energy before the crack increase is defined as

$$
U_{b}=\iint_{(V)} u d V
$$

where (according to Figs. 1 and 2)

$$
d V=b\left(z_{3}\right) \Delta a d z_{3} .
$$

Here, $b\left(z_{3}\right)$ is the cross-sectional width as the function of $z_{3}$.

The strain energy density, $u_{0}$, is equal to the area enclosed by the stress-strain curve [13-16] (Fig. 5). Therefore, the strain energy density can be written as

$$
u_{0 i}=\int_{0}^{\varepsilon} \sigma_{i}(\varepsilon) d \varepsilon, \quad i=1,2, \ldots, n
$$

The curvature, $\kappa_{3}$, of the multilayered beam cross section and the neutral axis coordinate, $z_{3 n_{3}}$, which are needed to solve the integral in Eq. (8), were determined from the equilibrium equations of the cross section (Fig. 2):

$$
\begin{gathered}
N=\sum_{i=1}^{i=n} \iint_{\left(A_{i}\right)} \sigma_{i} d A_{i}, \\
M=\sum_{i=1}^{i=n} \iint_{\left(A_{i}\right)} \sigma_{i} z_{3} d A_{i},
\end{gathered}
$$

where

$$
d A_{i}=b\left(z_{3}\right) d z_{3} .
$$

In order to facilitate the solution of integrals in Eqs. (9) and (10), $\varepsilon$ is replaced (see Fig. 2) as follows

$$
\varepsilon=\kappa_{3}\left(z_{3}-z_{3 n_{3}}\right) .
$$




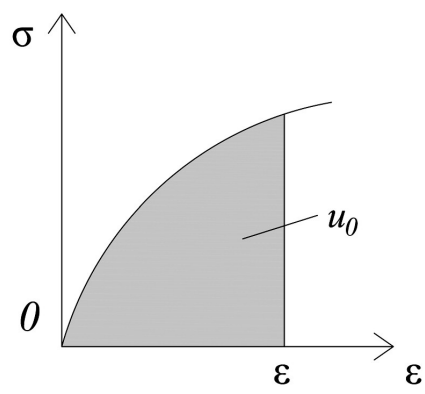

Fig. 5. Strain energy density.

Thus,

$$
\begin{gathered}
N=\sum_{i=1}^{i=n} \int_{z_{3 i}}^{z_{3 i+1}} \sigma_{i}\left[\kappa_{3}\left(z_{3}-z_{3 n_{3}}\right)\right] b\left(z_{3}\right) d z_{3}, \\
M=\sum_{i=1}^{i=n} \int_{z_{3 i}}^{z_{3 i+1}} \sigma_{i}\left[\kappa_{3}\left(z_{3}-z_{3 n_{3}}\right)\right] z_{3} b\left(z_{3}\right) d z_{3},
\end{gathered}
$$

where coordinates $z_{3 i}$ and $z_{3 i+1}$ are defined in Fig. 2 .

Unknown values $\kappa_{3}$ and $z_{3 n_{3}}$ can be obtained by solving Eqs. (13) and (14) as an algebraic system for the particular stress-strain relations (for this purpose, if necessary, the MatLab computer program may be used).

The strain energy (6) takes the form of

$$
U_{b}=\Delta a \sum_{i=1}^{i=n} \int_{z_{3 i}}^{z_{3 i+1}} u_{0 i} b\left(z_{3}\right) d z_{3} .
$$

In Eq. (15), $u_{0 i}$ are functions of $z_{3}$ [after solution of integrals (8), $\varepsilon$ should be replaced by $\kappa_{3}\left(z_{3}-z_{3 n_{3}}\right)$, in order to express $u_{0 i}$ via functions of $z_{3}$ to facilitate the solution of integrals in Eq. (15)].

The strain energy, $U_{a_{1}}$, in the lower crack arm after an increase in the crack length can be obtained via Eq. (15). However, $z_{3}, z_{3 n_{3}}$, and $n$ should be replaced by $z_{1}, z_{1 n_{1}}$, and $n_{L}$, respectively. Here, $z_{1 n_{1}}$ is the neutral axis coordinate of the lower crack arm cross section, and $n_{L}$ is the number of layers in the lower crack arm. A similar replacement can be achieved via Eqs. (13) and (14), in order to determine the neutral axis coordinate and the curvature of the lower crack arm, $\kappa_{1}$. Also, $M$ and $N$ in Eqs. (13) and (14) should be replaced by $M_{1}$ and $N_{1}$, respectively $\left[M_{1}\right.$ and $N_{1}$ are the bending moment and axial force in the lower crack arm cross section behind the crack front (Fig. 3)]. Therefore, the strain energy in the lower crack arm takes the following form:

$$
U_{a_{1}}=\Delta a \sum_{i=1}^{i=n_{L}} \int_{z_{1 i}}^{z_{1 i+1}} u_{0 i} b\left(z_{1}\right) d z_{1} .
$$


The next step of the analysis was to determine the strain energy in the upper crack arm, $U_{a_{2}}$. For this purpose, $z_{1}, z_{1 n_{1}}, \kappa_{1}, n_{L}, N_{1}$, and $M_{1}$ were replaced by $z_{2}, z_{2 n_{2}}$, $\kappa_{2}, n_{U}, N_{2}$, and $M_{2}$, respectively (Fig. 3) in Eqs. (13), (14), and (16). Here, $z_{2 n_{2}}$ is the neutral axis coordinate of the upper crack arm cross section, and $n_{U}$ is the number of layers in the upper crack arm (it is obvious that $n=n_{L}+n_{U}$ ). The bending moment, $M_{2}$, and the axial force, $N_{2}$, in the upper crack arm cross section behind the crack front were expressed in function of $M, N, M_{1}$, and $N_{1}$ by considering the equilibrium of the beam cross section (Figs. 2 and 3), i.e.,

$$
\begin{gathered}
N_{2}=N-N_{1}, \\
M_{2}=M-M_{1}+N\left(h_{C_{2}}-h_{C}\right)-N_{1}\left(h_{C_{2}}-h_{C_{1}}\right) .
\end{gathered}
$$

Therefore, the strain energy in the upper crack arm can be written as

$$
U_{a_{2}}=\Delta a \sum_{i=1}^{i=n_{U}} \int_{z_{2 i}}^{z_{2 i+1}} u_{0 i} b\left(z_{2}\right) d z_{2}
$$

The strain energy after the increase of the crack is derived by summation of Eqs. (16) and (19), i.e.,

$$
U_{a}=U_{a_{1}}+U_{a_{2}}=\Delta a \sum_{i=1}^{i=n_{L}} \int_{z_{1 i}}^{z_{1 i+1}} u_{0 i} b\left(z_{1}\right) d z_{1}+\Delta a \sum_{i=1}^{i=n_{U}} \int_{z_{2 i}}^{z_{2 i+1}} u_{0 i} b\left(z_{2}\right) d z_{2} .
$$

The final solution is obtained by substitution of Eqs. (15) and (20) into Eq. (5), i.e.,

$$
G=\frac{1}{b_{s}}\left[\sum_{i=1}^{i=n_{L}} \int_{z_{1 i}}^{z_{1 i+1}} u_{0 i} b\left(z_{1}\right) d z_{1}+\sum_{i=1}^{i=n_{U}} \int_{z_{2 i}}^{z_{2 i+1}} u_{0 i} b\left(z_{2}\right) d z_{2}-\sum_{i=1}^{i=n} \int_{z_{3 i}}^{z_{3 i+1}} u_{0 i} b\left(z_{3}\right) d z_{3}\right] .
$$

Equation (21) indicates that the solution does not depend on the crack advance, $\Delta a$. Also, it can be observed in Eq. (21) that the nonlinear solution can be found by using the bending moments and axial forces in the beam cross sections behind and ahead of the crack front. It is clear that Eq. (21) can be also applied to beam cross sections with two axes of symmetry.

Beams with rectangular cross-section are used very often in the engineering practice. For a rectangular cross section of width $b$ and height $2 h$, Eq. (21) can be rewritten as

$$
G=\sum_{i=1}^{i=n_{L}} \int_{z_{1 i}}^{z_{1 i+1}} u_{0 i} d z_{1}+\sum_{i=1}^{i=n_{U}} \int_{z_{2 i}}^{z_{2 i+1}} u_{0 i} d z_{2}-\sum_{i=1}^{i=n} \int_{z_{3 i}}^{z_{3 i+1}} u_{0 i} d z_{3}
$$

The curvature and the neutral axis coordinate can be found after substitution of $b\left(z_{3}\right)=b$ in Eqs. (13) and (14). Also,

$$
h_{C}=h, \quad h_{C_{1}}=\frac{h_{1}}{2}, \quad h_{C_{2}}=h_{1}+\frac{h_{2}}{2}
$$

should be substituted into Eq. (18). 
2. Investigation of the Multilayered DCB. Equation (22) was applied to investigate the nonlinear fracture behavior of the DCB multilayered configuration (Fig. 6). There is a longitudinal crack of length $a$ located arbitrarily along the beam height (the lower and upper crack arm thickness being $h_{1}$ and $h_{2}$, respectively). The beam cross section is a rectangle of width $b$ and height $2 h$. The loading consists of two transverse forces, $F$, applied to the crack arm ends as illustrated in Fig. 6.

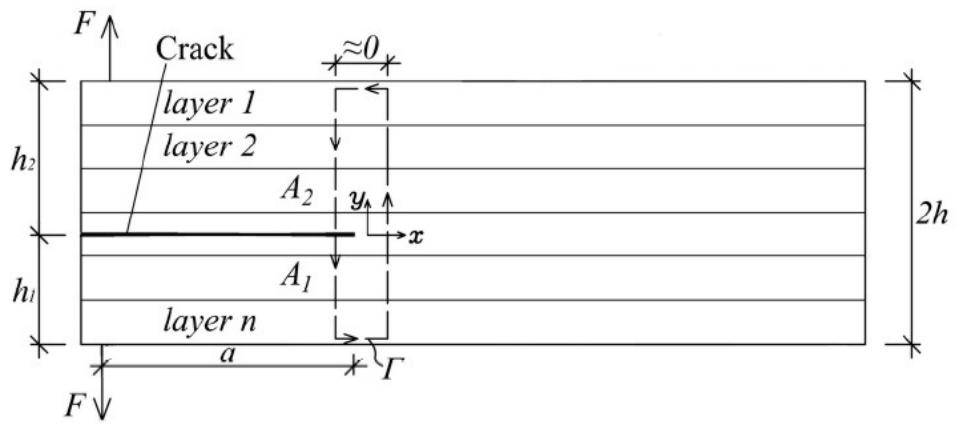

Fig. 6. The DCB multilayered configuration.

It was assumed that the beam layers mechanical behavior can be described by power-law stress-strain relations, i.e.,

$$
\sigma_{i}=H_{1 i} \varepsilon_{i}^{n_{1 i}}, \quad i=1,2, \ldots, n,
$$

where $\sigma_{i}$ is the normal stress distribution, $\varepsilon_{i}$ is the linear strains distribution, $H_{1 i}$ and $n_{1 i}$ are material constants in the $i$ th layer of the beam. It should be specified that $0<n_{1 i} \leq 1$.

The lower crack arm curvature, $\kappa_{1}$, and the neutral axis coordinate, $z_{1 n_{1}}$, were determined from the equilibrium Eqs. (13) and (14). For this purpose, $N=0, n=n_{L}$, $b\left(z_{3}\right)=b$, and $\sigma_{i}\left[\kappa_{3}\left(z_{3}-z_{3 n_{3}}\right)\right]=H_{1 i}\left[\kappa_{1}\left(z_{1}-z_{1 n_{1}}\right)\right]^{n_{1 i}}$ were substituted in Eqs. (13) and (14). The solutions of the integrals in Eqs. (13) and (14) were found as

$$
\begin{gathered}
N=b \sum_{i=1}^{n_{L}}\left\{\frac{H_{1 i} \kappa_{1}^{n_{1 i}}}{n_{1 i}+1}\left[\left(z_{1 i+1}-z_{1 n_{1}}\right)^{n_{1 i}+1}-\left(z_{1 i}-z_{1 n_{1}}\right)^{n_{1 i}+1}\right]\right\}=0, \\
M=b \sum_{i=1}^{n_{L}}\left\{\frac{H_{1 i} \kappa_{1}^{n_{1 i}}}{n_{1 i}+2}\left[\left(z_{1 i+1}-z_{1 n_{1}}\right)^{n_{1 i}+2}-\left(z_{1 i}-z_{1 n_{1}}\right)^{n_{1 i}+2}\right]+\right. \\
\left.+\frac{H_{1 i} \kappa_{1}^{n_{1 i}} z_{1 n_{1}}}{n_{1 i}+1}\left[\left(z_{1 i+1}-z_{1 n_{1}}\right)^{n_{1 i}+1}-\left(z_{1 i}-z_{1 n_{1}}\right)^{n_{1 i}+1}\right]\right\},
\end{gathered}
$$

where $M=-F a$ is the bending moment in the lower crack arm behind the crack tip (Fig. 6).

It is clear that at $n_{1 i}=1$ and $H_{1 i}=E$ (here $E$ is the elastic modulus) Eq. (24) transforms into Hooke's law. This fact was used here to verify Eq. (26). For this purpose, $n_{1 i}=1, H_{1 i}=E$, and $n_{L}=1$ were substituted in Eq. (26). This yields the known formula for the curvature of a linear-elastic homogeneous beam 


$$
\kappa_{1}=\frac{12 M}{E b h_{1}^{3}} \text {. }
$$

Equations (25) and (26) can be solved with respect to $\kappa_{1}$ and $z_{1 n_{1}}$ by using the MatLab software program (at $n_{1 i} \neq 1$ ). Then, $\kappa_{1}$ and $z_{1 n_{1}}$ are substituted in Eqs. (12) and (24). After that, the strain energy density derived via Eq. (8) is reduced to

$$
u_{0 i}=\frac{H_{1 i}\left[\kappa_{1}\left(z_{1}-z_{1 n_{1}}\right)\right]^{n_{1 i}+1}}{n_{1 i}+1}, \quad i=1,2, \ldots, n_{L} .
$$

The upper crack arm curvature, $\kappa_{2}$, and the neutral axis coordinate, $z_{2 n_{2}}$, were determined also from Eqs. (25) and (26). For this purpose, $n_{L}, \kappa_{1}$, and $z_{1 n_{1}}$ were replaced with $n_{U}, \kappa_{2}$, and $z_{2 n_{2}}$, respectively. Then, the MatLab computer program was used to solve Eqs. (25) and (26) with respect to $\kappa_{2}$ and $z_{2 n_{2}}$. The strain energy density was obtained by Eq. (28). For this purpose, $\kappa_{1}$ and $z_{1 n_{1}}$ were replaced with $\kappa_{2}$ and $z_{2 n_{2}}$, respectively, i.e.,

$$
u_{0 i}=\frac{H_{1 i}\left[\kappa_{2}\left(z_{2}-z_{2 n_{2}}\right)\right]^{n_{1 i}+1}}{n_{1 i}+1}, \quad i=1,2, \ldots, n_{U}
$$

The strain energy ahead of the crack tip is zero in the DCB. Therefore, Eq. (22) was rewritten as

$$
G=\sum_{i=1}^{i=n_{L}} \int_{z_{1 i}}^{z_{1 i+1}} u_{0 i} d z_{1}+\sum_{i=1}^{i=n_{U}} \int_{z_{2 i}}^{z_{2 i+1}} u_{0 i} d z_{2}
$$

Finally, the strain energy densities Eqs. (28) and (29) were substituted in Eq. (30) and the integrals were solved. It was obtained

$$
\begin{aligned}
& G=\sum_{i=1}^{n_{L}} \frac{H_{1 i} n_{1 i}}{\left(n_{1 i}+1\right)\left(n_{1 i}+2\right)} \kappa_{1}^{n_{1 i}+1}\left[\left(z_{1 i+1}-z_{1 n_{1}}\right)^{n_{1 i}+2}-\left(z_{1 i}-z_{1 n_{1}}\right)^{n_{1 i}+2}\right]+ \\
& +\sum_{i=1}^{n_{U}} \frac{H_{1 i} n_{1 i}}{\left(n_{1 i}+1\right)\left(n_{1 i}+2\right)} \kappa_{2}^{n_{1 i}+1}\left[\left(z_{2 i+1}-z_{2 n_{2}}\right)^{n_{1 i}+2}-\left(z_{2 i}-z_{2 n_{2}}\right)^{n_{1 i}+2}\right] .
\end{aligned}
$$

Equation (31) expresses the strain energy release rate in the DCB multilayered configuration with taking into account the material nonlinearity by using a power-law stress-strain relation Eq. (24).

It was substituted $n_{L}=1, n_{U}=1, n_{1 i}=1, H_{1 i}=E$, and $h_{1}=h_{2}=h$ in Eq. (31) for verification. It was obtained

$$
G=\frac{12 M^{2}}{E b^{2} h^{3}}
$$


where $M=F a$. Equation (32) coincides with the expression for the strain energy release rate in the linear-elastic homogeneous DCB when the crack is in the beam midplane [1], which is an indication for correctness of Eq. (31).

Another verification of Eq. (31) was performed by analyzing the nonlinear fracture in the DCB multilayered configuration with the help of the $J$-integral [17-20].

The $J$-integral was solved by using an integration contour, $\Gamma$, that consists of the beam cross sections behind and ahead of the crack tip (Fig. 6). It is obvious that the $J$-integral value is other than zero only in segments $A_{1}$ and $A_{2}$ of the integration contour (segments $A_{1}$ and $A_{2}$ coincide with cross section of the lower and upper crack arm, respectively). Therefore, the $J$-integral solution was obtained by summation:

$$
J=J_{A_{1}}+J_{A_{2}},
$$

where $J_{A_{1}}$ and $J_{A_{2}}$ are the $J$-integral values in the integration contour segments $A_{1}$ and $A_{2}$, respectively.

The $J$-integral in segment $A_{1}$ was written as

$$
J_{A_{1}}=\sum_{i=1}^{n_{L}} \int_{z_{1 i}}^{z_{1 i+1}}\left[u_{0 i} \cos \alpha-\left(p_{x i} \frac{\partial u}{\partial x}+p_{y i} \frac{\partial v}{\partial x}\right)\right] d s
$$

where $u_{0 i}$ is the strain energy density, $\alpha$ is the angle between the outwards normal vector to the contour of integration and the crack direction, $p_{x i}$ and $p_{y i}$ are the components of the stress vector, $u$ and $v$ are the components of the displacement vector with respect to the crack tip coordinate system $x y$, and $d s$ is a differential element along the integration contour $\Gamma$.

The $J$-integral components in segment $A_{1}$ were written as

$$
\begin{gathered}
p_{x i}=-\sigma_{i}=-H_{1 i} \varepsilon^{n_{1 i}}, \quad p_{y i}=0 \\
d s=d z_{1}, \quad \frac{\partial u}{\partial x}=\varepsilon=\kappa_{1}\left(z_{1}-z_{1 n_{1}}\right), \quad \text { and } \quad \cos \alpha=-1,
\end{gathered}
$$

where $\kappa_{1}$ and $z_{1 n_{1}}$ were determined from Eqs. (25) and (26).

After substitution of Eqs. (28), (35), and (36) in Eq. (34), the $J$-integral solution in segment $A_{1}$ was written as

$$
J_{A_{1}}=\sum_{i=1}^{n_{L}} \frac{H_{1 i} n_{1 i}}{\left(n_{1 i}+1\right)\left(n_{1 i}+2\right)} \kappa_{1}^{n_{1 i}+1}\left[\left(z_{1 i+1}-z_{1 n_{1}}\right)^{n_{1 i}+2}-\left(z_{1 i}-z_{1 n_{1}}\right)^{n_{1 i}+2}\right] .
$$

The $J$-integral solution in segment $A_{2}$ was found also by Eq. (37). For this purpose, $n_{L}, \kappa_{1}$, and $z_{1 n_{1}}$ were replaced with $n_{U}, \kappa_{2}$, and $z_{2 n_{2}}$, respectively:

$$
J_{A_{2}}=\sum_{i=1}^{n_{U}} \frac{H_{1 i} n_{1 i}}{\left(n_{1 i}+1\right)\left(n_{1 i}+2\right)} \kappa_{2}^{n_{1 i}+1}\left[\left(z_{2 i+1}-z_{2 n_{2}}\right)^{n_{1 i}+2}-\left(z_{2 i}-z_{2 n_{2}}\right)^{n_{1 i}+2}\right] .
$$


The $J$-integral final nonlinear solution is obtained by substitution of Eqs. (37) and (38) into Eq. (33), i.e.,

$$
\begin{aligned}
& J=\sum_{i=1}^{n_{L}} \frac{H_{1 i} n_{1 i}}{\left(n_{1 i}+1\right)\left(n_{1 i}+2\right)} \kappa_{1}^{n_{1 i}+1}\left[\left(z_{1 i+1}-z_{1 n_{1}}\right)^{n_{1 i}+2}-\left(z_{1 i}-z_{1 n_{1}}\right)^{n_{1 i}+2}\right]+ \\
& +\sum_{i=1}^{n_{U}} \frac{H_{1 i} n_{1 i}}{\left(n_{1 i}+1\right)\left(n_{1 i}+2\right)} \kappa_{2}^{n_{1 i}+1}\left[\left(z_{2 i+1}-z_{2 n_{2}}\right)^{n_{1 i}+2}-\left(z_{2 i}-z_{2 n_{2}}\right)^{n_{1 i}+2}\right] .
\end{aligned}
$$

The fact that Eq. (39) coincides with Eq. (31) is a general verification of the strain energy release rate nonlinear solution of Eq. (21) derived in the present paper.

Conclusions. The longitudinal fracture behavior of multilayered beams was studied theoretically with taking into account the material nonlinearity. An analysis was developed for the strain energy release rate by using the classical beam theory. Each beam layer may have different thickness. The crack may be located arbitrary along the beam height. Moreover, the stress-strain relation itself may be different in each layer. It should be mentioned that the strain energy release rate was expressed in a function of the bending moments and axial loads in the beam cross sections ahead and behind the crack front, which enables nonlinear fracture investigations of multilayered beams to be carried out in a closed analytical form. The analysis reported in the present article contributes towards the understanding of longitudinal fracture in multilayered beams experiencing material nonlinearity.

\section{Резюме}

У рамках класичної теорії балок на основі критерію швидкості звільнення енергії деформації виконано аналітичний розрахунок міцності багатошарових балок із поздовжньою тріщиною з урахуванням непружності матеріалу. Отримані розрахункові співвідношення можна використати до багатошарових балок із шарами різної товщини, напружено-деформований стан кожного 3 них може описуватися індивідуальним нелінійним рівнянням напруга-деформація. Для поздовжньої тріщини 3 довільним розташуванням по висоті балки визначається швидкість звільнення енергії деформації як функція згинальних моментів і осьових навантажень, що діють у перетинах балки, розташованих попереду і позаду фронту тріщини. Таким чином можна визначити умови руйнування багатошарових балок у замкнутому вигляді. Запропонований підхід дозволяє виявити особливості непружного деформування і руйнування багатошарових балок із тріщиною.

1. J. W. Hutchinson and Z. Suo, "Mixed mode cracking in layered materials," Adv. Appl. Mech., 29, 63-191 (1991).

2. B. D. Davidson and V. Sundararaman, "A single-leg bending test for interfacial fracture toughness determination," Int. J. Fracture, 78, 193.-210 (1996).

3. D. T. S. Yeung, D. C. C. Lam, and M. M. F. Yuen, "Specimen design for mixed mode interfacial fracture properties measurement in electronic packages," J. Electron. Packaging, 122, 67-72 (2000).

4. J. A. Narin, "Energy release rate analysis of adhesive and laminate double cantilever beam specimens emphasizing the effect of residual stresses," Int. J. Adhes. Adhes., 20, 59-70 (1999). 
5. F. G. Guadette, A. E. Giannapoulos, and S. Suresh, "Interface cracks in layered materials subjected to a uniform temperature change," Int. J. Fracture, 110, No. 4, 325-349 (2001).

6. J. Jiao, G. K. Gurumurthy, E. J. Kramer, et al., "Measurement of interfacial fracture toughness under combined mechanical and thermal stress," J. Electron. Packaging, 120, 349-353 (1998).

7. C. H. Hsuesh, W. H. Tuan, and W. C. J. Wei, "Analyses of steady-state interface fracture of elastic multilayered beams under four-point bending," Scripta Mater., 60, $721-724$ (2009).

8. S.-C. Her and W.-B. Su, "Interfacial fracture toughness of multilayered composite structures," Strength Mater., 47, No. 1, 186-191 (2015).

9. A. A. Ilyushin, Plasticity [in Russian], Vol. 1: Elastic-Plastic Strains, OGIZ, Moscow (1948).

10. L. M. Kachanov, Fundamentals of the Theory of Plasticity [in Russian], Nauka, Moscow (1969).

11. J. Lubliner, Plasticity Theory (Revised edition), University of California, Berkeley, CA (2006).

12. J. Chakrabarty, Theory of Plasticity, Elsevier/Butterworth-Heinemann, Oxford (2006).

13. N. J. Hoff, The Analysis of Structures, John Wiley\&Sons, New York (1956).

14. A. Nadai, Theory of Flow and Fracture of Solids, Volume 2, McGraw-Hill, New York (1963).

15. F. B. Seely and J. O. Smith, Advanced Mechanics of Materials, John Wiley\&Sons, New York (1967).

16. K. Washizu, Variational Methods in Elasticity and Plasticity, Pergamon Press, Oxford (1974).

17. J. R. Rice, "A path independent integral and the approximate analysis of strain concentration by notches and cracks," J. Appl. Mech., 35, 379-386 (1968).

18. G. Cherepanov, Brittle Materials Fracture Mechanics [in Russian], Nauka, Moscow (1974).

19. D. Broek, Elementary Engineering Fracture Mechanics, Springer (1982).

20. V. I. Rizov, "Nonlinear fracture of functionally graded beams under mode II loading conditions," Strength Mater., 48, No. 5, 677-686 (2016). 